\title{
The National Health Plan 2030: Its Purpose and Directions of Development
}

\author{
Yumi Oh \\ Korea Health Promotion Institute, Seoul, Korea
}

The National Health Plan 2030 (HP2030) started to be prepared in 2017 and was completed and announced in December 2020. This study presents an overview of how it was established, the major changes in policies, its purpose, and future directions. This study analyzed the steps taken in the past 4 years to establish HP2030 and reviewed major issues at the international and governmental levels based on an evaluation of HP2020 and its content. HP2030 establishes 6 divisions and 28 topic areas, and it will continue to expand investments in health with a total budget of 2.5 trillion Korean won. It also established goals to enhance health equity for the first time, with the goal of calculating healthy life expectancy in a way that reflects the circumstances of Korea and reducing the gap in income and healthy life expectancy between regions. The establishment of HP2030 is significant in that it constitutes a sustainable long-term plan with sufficient preparation, contains policy measures that everyone participates in and makes together, and works towards improvements in universal health standards and health equity. With the announcement of HP2030, which includes goals and directions of the national health policy for the next 10 years, it will be necessary to further strengthen collaboration with relevant ministries, local governments, and agencies in various fields to concretize support for prevention-centered health management as a national task and to develop a health-friendly environment that considers health in all policy areas.

Key words: National Health Plan, Health policy, Health equity, Life expectancy

\section{INTRODUCTION}

Korea's socioeconomic structure continues to change, and the government has systematically established and implemented a national long-term comprehensive health promotion plan to improve the health and quality of life for its people. This plan plays an important role in providing a basic framework for the development of national health policy from the long-

Received: April 12, 2021 Accepted: May 7, 2021

Corresponding author: Yumi Oh

Korea Health Promotion Institute, 173 Toegye-ro, Jung-gu,

Seoul 04554, Korea

E-mail: oyumi@khealth.or.kr

This is an Open Access article distributed under the terms of the Creative Commons Attribution Non-Commercial License (https://creativecommons.org/licenses/by$\mathrm{nc} / 4.0 /$ ) which permits unrestricted non-commercial use, distribution, and reproduction in any medium, provided the original work is properly cited. term perspective, and is an important policy tool that reflects the government's goals in the fields of health promotion and sustainable health [1]. The Ministry of Health and Welfare establishes government-wide plans that suggest long-term policy directions, and the National Health Plan (hereinafter referred to as the "HP"), which reflects the directions and tasks of health policy for the next 10 years, is established every 10 years and supplemented every 5 years [2]. The National Health Plan 2030 (HP2030) was approved by the Health Promotion Policy Review Committee of the Ministry of Health and Welfare in December 2020 [3]. The relevant ministries discussed and approved major tasks for extending the healthy life expectancy (HLE) and improving health equity at the Second Ministerial Meeting on Education, Society and Culture in January 2021. They agreed to the need for each ministry and local government to take interest and invest efforts towards achieving these goals (e.g., 


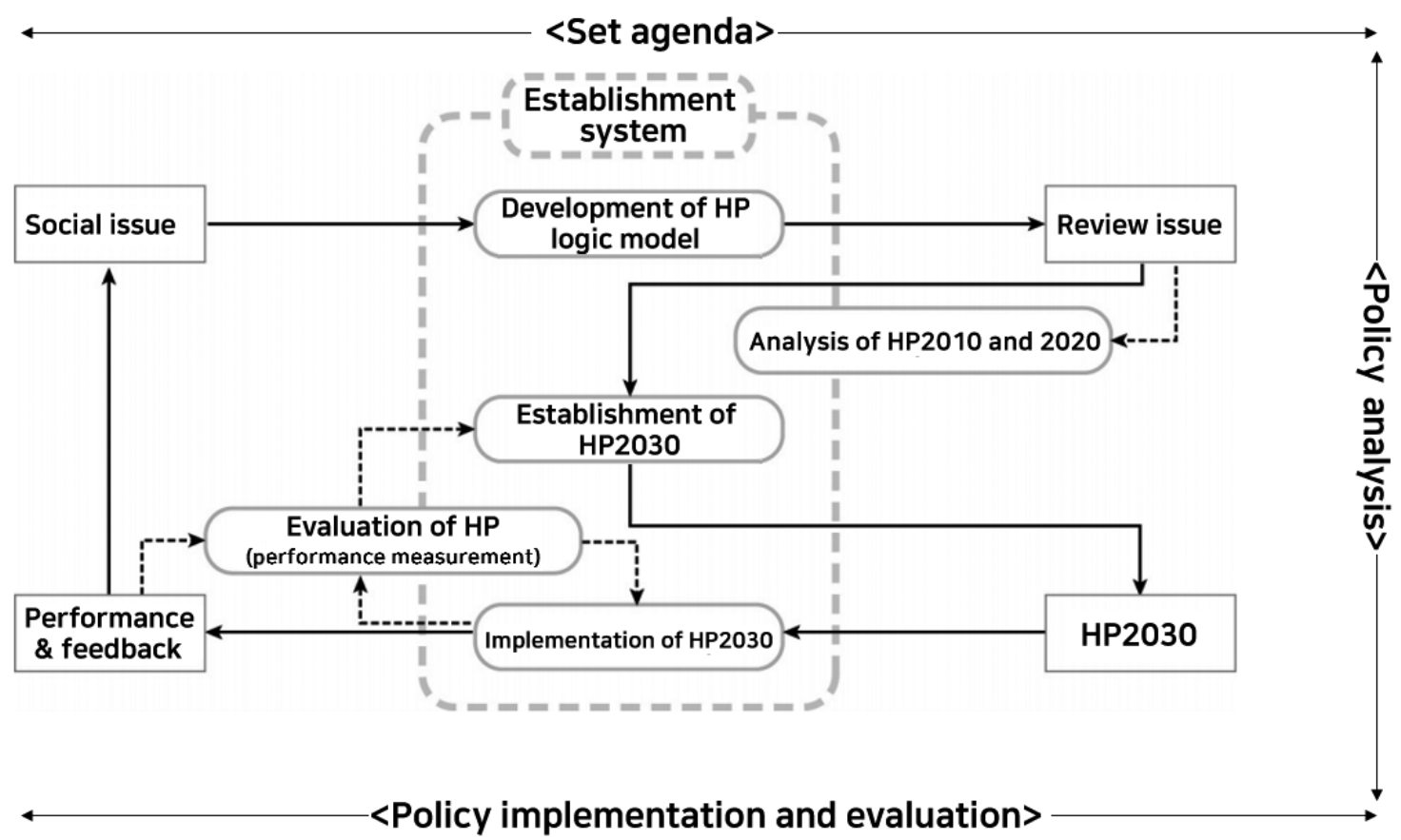

Figure 1. Diagram of steps taken to establish the National Health Plan 2030 (HP2030). HP, National Health Plan. Modified from: Jeong et al. Therories of policy sciences. Seoul: Dwamyung; 2017 [3].

by considering health aspects in their policies), and announced the details. This study presents the process of establishing HP2030 and the major issues involved in that process, and lays the foundation for effective combinations of regional health promotion policies and public policies in the future.

\section{Conceptual Framework}

To set the agenda for and to establish the HP, a structural framework was organized [4], as follows: agenda-setting $\rightarrow$ policy analysis $\rightarrow$ policy implementation and evaluation, followed by review and establishment of the plan (Figure 1) [3].

This review analyzed the preparation process of HP2030 from 2017 to 2020, and examined changes and implications of the establishment of HP 2030 based on the analysis. To achieve this goal, the key results of each committee meeting held over the past 4 years, research reports for evaluation and establishment, and the government report on the HP were analyzed. This review also analyzed the role and significance of international policies, such as the United Nations (UN) Sustainable Development Goals (SDGs) [5] and the World Health Organization (WHO) prevention plan for non-communicable diseases (NCDs) [6], the national health promotion comprehensive plan at the central government level, long-term plans for each area, and the connection between regional health plans and integrated health promotion programs [7] at the local government level.

\section{NATIONAL HEALTH PALN: PRGRESS AND RESULTS}

In the late 1990s, when the foundation for health promotion policies in Korea was built, such as the enactment of the Health Promotion Act in 1995 and the establishment of the Health Promotion Fund in 1997, the need for a long-term health promotion policy emerged. The Ministry of Health and Welfare responded by establishing and implementing long-term plans under the name of the Health Plan [8]. This is a statutory plan based on the National Health Promotion Act and is the highest comprehensive plan in the health sector [9]. A total of 3 plans have been established and announced: HP2010, HP2020, and HP2030. Since these are long-term plans, each Health Plan is a 10-year plan established according to changes in the social environment, and the plan is evaluated and revised every 5 years in accordance with the law. The first plan, HP2010, was launched for the period of 2002-2010, and the second plan was then announced for the period of 2006-2010 based on the interim evaluation. The third plan, HP2020, was for 2011- 
2020, and the fourth plan was implemented from 2016 to 2020 based on an interim evaluation [10]. HP2030 is scheduled to be implemented from 2021 to 2030 as the fifth plan, and the sixth plan will be put in place from 2026 to 2030 on the basis of a future evaluation.

The long-term nature of this plan necessitated a long-term perspective. In 2017, preparations for the establishment of the HP2030 plan and the evaluation of HP2020 began with the establishment of an implementation system and an assessment of pending issues [11]. HP2020 (the third and fourth plans) was evaluated through this process, and it was found that the goals were achieved in terms of improving 12 out of the 19 indicators. Of particular note, these indicators were improved through the intensification of regulations on health hazards and community-centered health promotion policies for the prevention and management of chronic diseases. However, the high-risk alcohol use rate, hypertension, and diabetes worsened over the past decade, needing improvement. Regarding financial resources [12], the amount of financial resources in the health promotion funds expanded after the increase in tobacco prices in 2015 , but only $10 \%$ of the budget is spent on healthy life promotion initiatives, meaning that limitations in this regard continue to exist. Based on these evaluation results, the process of establishing HP2030 began.

For HP2030, the goal was set to derive policy tasks and goals that the central and local governments should pursue over the next 10 years, and the plan was established through an extensive consultation process between private sector experts and government officials to ensure the feasibility of the policies [13]. As part of the plan, logical connections, policy effectiveness, and the appropriateness of performance targets and indicators were improved, and health equity was reflected in all programs and goals. As a result, the Ministry of Health and Welfare developed 28 topic areas for HP2030 over 6 divisions and set 420 performance indicators to facilitate the success of the plan. In addition, 37 leading health indicators were set and monitored considering their importance (Table 1). The ministry also announced that it will continue to expand related investments through consultations with the fiscal authorities using a budget of approximately 2.5 trillion Korean won [14].

Under the vision of creating a "Society Where All People Enjoy Lifelong Health," HP2030 set the general goals of extending HLE and improving health equity by reducing the health gap by income and region. The data source for HLE changed from WHO data used in the fifth HP to Korean HLE data developed through a research and development project [15] that started in 2018. HP2030 aims to extend the HLE from 70.4 years as of 2018 to 73.3 years by 2030. No specific goal for health equity improvement was set in earlier HPs. In contrast, HP2030 intends to reduce the HLE gap according to income and region by reducing the HLE gap between the top $20 \%$ income group and the bottom $20 \%$ income group to 7.6 years by 2030 and reducing the gap across regions, which is currently increasing, to the level of 2.9 years by 2030 .

\section{MAJOR ISSUES INVOLVED WITH THE ESTABLISHMENT OF NATIONAL HEALTH PLAN 2030}

\section{Establishment of Rational Policies}

In the past, HPs performed multi-year evaluations in a 6-month period, and the results were not sufficiently reflected in the following plan. HP2030 planned and established a research project to improve these shortcomings. First, to evaluate HP2020, the Korea Health Promotion Institution evaluated the achievement of the performance indicators every year and performed a quantitative evaluation of HP2020 based on the yearly assessments. A quantitative analysis was conducted based on a qualitative evaluation of HP2020 [16], along with the basic research for the evaluation, and the results were reflected in the establishment of HP2030. Shortly thereafter, a study on the development of the logic model [17], the highest-level framework of HP2030, began; through this process, the general goals, basic principles, major areas, and sub-divisions were developed and systematized. Plans were established for each division through the development of the HP2030 establishment strategy to systematize the plan [18]. Furthermore, a study was performed to calculate the Korean HLE in order to establish the general goals of HP2030, and indicators for HLE and health equity were developed [15].

\section{Preparation of Strategies Based on the Logic Model and Basic Implementation Principles}

Plans for the HP2030 were established in accordance with the 6 basic implementation principles. The previous HP did have basic implementation principles, but HP2030 stipulated the basic framework from the stage of developing the basic policy framework and established the details of the strategy based on the framework. The basic principles were established 
Table 1. National Health Plan 2030 indicators

\begin{tabular}{|c|c|c|c|c|c|c|}
\hline \multirow{2}{*}{$\begin{array}{l}\text { Divisions } \\
\text { (indicators, LHI) }\end{array}$} & \multirow{2}{*}{$\begin{array}{c}\text { Topic areas } \\
(\mathrm{n}=\mathbf{6})\end{array}$} & \multirow{2}{*}{$\begin{array}{l}\text { Indicators } \\
(\mathrm{n}=417)\end{array}$} & \multirow{2}{*}{$\underset{(n=37)}{\text { LHI }}$} & \multicolumn{3}{|c|}{ Equity indicators } \\
\hline & & & & Gender $(n=50)$ & Income $(n=38)$ & Region $(n=10)$ \\
\hline \multirow{5}{*}{$\begin{array}{l}\text { Practice healthy lifestyle } \\
(106 / 8)\end{array}$} & Tobacco use & 36 & 2 & 10 & 6 & - \\
\hline & Alcohol use & 23 & 2 & 6 & 3 & - \\
\hline & Nutrition & 20 & 1 & - & 10 & - \\
\hline & Physical activity & 11 & 2 & 1 & 2 & - \\
\hline & Oral conditions & 16 & 1 & - & 5 & - \\
\hline \multirow{4}{*}{$\begin{array}{l}\text { Improve mental health } \\
(52 / 6)\end{array}$} & Suicide & 20 & 3 & 1 & - & 1 \\
\hline & Dementia & 20 & 1 & 1 & - & 2 \\
\hline & Addiction & 7 & 1 & 1 & 1 & \\
\hline & Local community mental health & 5 & 1 & - & - & - \\
\hline \multirow{4}{*}{$\begin{array}{l}\text { Prevent and manage } \\
\text { non-communicable } \\
\text { diseases }(81 / 10)\end{array}$} & Cancer & 14 & 2 & 3 & - & 3 \\
\hline & $\begin{array}{l}\text { Cardio-cerebrovascular disease } \\
\text { (hypertension, diabetes) }\end{array}$ & 34 & 5 & 2 & 2 & - \\
\hline & Obesity & 16 & 2 & 5 & 3 & - \\
\hline & Injury prevention & 17 & 1 & 1 & 1 & - \\
\hline \multirow{3}{*}{$\begin{array}{l}\text { Prevent and manage } \\
\text { infection and } \\
\text { diseases related to } \\
\text { climate change }(49 / 3)\end{array}$} & $\begin{array}{l}\text { Prevention and management of } \\
\text { communicable diseases }\end{array}$ & 20 & 1 & 1 & - & - \\
\hline & $\begin{array}{l}\text { Preparation and response to } \\
\text { communicable disease crises }\end{array}$ & 21 & 1 & - & - & - \\
\hline & Diseases related to climate change & 8 & 1 & - & - & - \\
\hline \multirow{7}{*}{$\begin{array}{l}\text { Manage health for } \\
\text { population groups } \\
(112 / 9)\end{array}$} & Infants & 7 & 1 & 1 & - & - \\
\hline & Children and adolescents & 15 & 2 & 5 & - & - \\
\hline & Women & 7 & 1 & - & - & - \\
\hline & Older adults & 25 & 2 & 8 & 3 & 4 \\
\hline & People with disabilities & 29 & 1 & - & - & - \\
\hline & Workforce & 13 & 1 & 4 & - & - \\
\hline & Military & 16 & 1 & - & - & - \\
\hline \multirow[t]{5}{*}{$\begin{array}{l}\text { Develop health-friendly } \\
\text { environment (49/1) }\end{array}$} & $\begin{array}{l}\text { Improvement of a health-friendly legal } \\
\text { system }\end{array}$ & 4 & - & - & - & - \\
\hline & Improvement of health literacy & 7 & 1 & - & 2 & - \\
\hline & $\begin{array}{l}\text { Application of innovative information } \\
\text { technology }\end{array}$ & 2 & - & - & - & - \\
\hline & Procurement and management of finances & 1 & - & - & - & - \\
\hline & $\begin{array}{l}\text { Expansion and supplementation of local } \\
\text { community resources and establishment } \\
\text { of governance }\end{array}$ & 3 & - & - & - & - \\
\hline
\end{tabular}

LHI, leading health indicator.

through a research project and confirmed through expert and government committee reviews.

\section{Structures of the Divisions and Topic Areas}

Changes were made in the sub-divisions and topic areas. "Practice Healthy Lifestyles" and "Improve Mental Health" were set up as divisions to maintain a balance between physical and mental health and elevate mental health management from a topic area to a division to emphasize its importance. A balance was also sought between non-communica- ble diseases and communicable diseases by introducing divisions such as "Prevent and Manage Non-communicable Diseases" and "Prevent and Manage Diseases Related to Climate Change." For environmental diseases, the plan also established an area reflecting future health issues such as diseases related to climate change. The "Develop a Health-Friendly Environment" division was established by adding topics that can incorporate responses to international changes, such as health literacy. 


\section{Development and Application of Healthy Life} Expectancy as an Indicator

Through research that made it possible to calculate the Korean $\mathrm{HLE}$, health equity indicators between regions and income were also calculated. The HLE was 70.4 years as of 2018, and the HP aims to extend it by 2.9 years, with the goal of raising it to 73.3 years by 2030. Looking at the HLE by gender, the HP aims to extend women's HLE by 2.6 years from 72.4 years in 2018 to 75.0 years in 2030, and men's HLE by 3.1 years from
68.3 years as of 2018 to 71.4 years in 2030. The goal of HP2030 is to increase health equity by extending the HLE by 2.9 years overall and to alleviate the gap according to income and region to increase health equity (Figure 2) [19].

To improve health equity according to income, the plan aims to reduce the HLE gap between the top $20 \%$ income group and the bottom $20 \%$ income group from the current 8.1 years to 7.6 years by 2030. To improve health equity by region, the plan aims to manage the HLE gap from the current 2.7

\begin{tabular}{|c|c|c|c|c|c|c|}
\hline Vision & \multicolumn{6}{|c|}{ Society where all people enjoy lifelong health } \\
\hline & \multicolumn{6}{|c|}{$\rightarrow$} \\
\hline $\begin{array}{c}\text { General } \\
\text { goals }\end{array}$ & \multicolumn{3}{|c|}{ Extension of healthy life expectancy } & \multicolumn{3}{|c|}{$\begin{array}{c}\text { Improvement on health equity } \\
\text { (gap in income and healthy life expectancy } \\
\text { between regions) }\end{array}$} \\
\hline $\begin{array}{c}\text { Basic } \\
\text { principles }\end{array}$ & $\begin{array}{l}\text { (1) Reflec } \\
\text { (2) Enhan } \\
\text { (3) Apply } \\
\text { (4) Develc } \\
\text { (5) Ensure } \\
\text { (6) All rel }\end{array}$ & $\begin{array}{l}\text { alth primaril } \\
\text { he level of ur } \\
\text { ll life-cycle s } \\
\text { health-frien } \\
\text { opportunity } \\
\text { sectors inte }\end{array}$ & $\begin{array}{l}\text { the establishmen } \\
\text { rsal health and in } \\
\text { es and places of } \\
\text { environment } \\
\text { anyone to partici } \\
\text { ting and collabora }\end{array}$ & $\begin{array}{l}\text { f every policy of } \\
\text { cove health equit } \\
\text { ng } \\
\text { te to build and e } \\
\text { g with each oth }\end{array}$ & $\begin{array}{l}\text { e nation and lo } \\
\text { simultaneously } \\
\text { y the plan tog }\end{array}$ & $\begin{array}{l}\text { al communities } \\
\text { her }\end{array}$ \\
\hline & & & 7 & $2-$ & & \\
\hline Divisions & $\begin{array}{l}\text { Practice } \\
\text { healthy } \\
\text { lifestyles }\end{array}$ & $\begin{array}{l}\text { Improve } \\
\text { mental } \\
\text { health }\end{array}$ & $\begin{array}{c}\text { Prevent and } \\
\text { manage non- } \\
\text { communicable } \\
\text { diseases }\end{array}$ & $\begin{array}{l}\text { Prevent and } \\
\text { manage } \\
\text { diseases } \\
\text { related to } \\
\text { climate change }\end{array}$ & $\begin{array}{l}\text { Manage } \\
\text { health for } \\
\text { specific } \\
\text { population } \\
\text { groups }\end{array}$ & $\begin{array}{l}\text { Develop a } \\
\text { health-friendly } \\
\text { environment }\end{array}$ \\
\hline $\begin{array}{l}\text { Topic } \\
\text { areas }\end{array}$ & $\begin{array}{l}\text { - Tobacco } \\
\text { use } \\
\text { - Alcohol } \\
\text { use } \\
\text { - Nutrition } \\
\text { - Physical } \\
\text { activity } \\
\text { - Oral } \\
\text { conditions }\end{array}$ & $\begin{array}{l}\text { - Suicide } \\
\text { - Dementia } \\
\text { - Addiction } \\
\text { - Local } \\
\text { community } \\
\text { mental } \\
\text { health }\end{array}$ & $\begin{array}{l}\text { - Cancer } \\
\text { - Cardio- } \\
\text { cerebrovascular } \\
\text { disease } \\
\text { (hypertension, } \\
\text { diabetes) } \\
\text { - Obesity } \\
\text { - Injury } \\
\text { prevention }\end{array}$ & $\begin{array}{l}\text { - Prevention and } \\
\text { management of } \\
\text { communicable } \\
\text { disease } \\
\text { - Preparation } \\
\text { and response to } \\
\text { communicable } \\
\text { disease crises } \\
\text { - Diseases } \\
\text { related to } \\
\text { climate } \\
\text { change }\end{array}$ & $\begin{array}{l}\text { - Infants } \\
\text { - Children and } \\
\text { adolescents } \\
\text { - Women } \\
\text { - Older adults } \\
\text { - People with } \\
\text { disabilities } \\
\text { - Workforce } \\
\text { - Military }\end{array}$ & $\begin{array}{l}\text { - Improvement of } \\
\text { a health-friendly } \\
\text { legal system } \\
\text { - Improvement of } \\
\text { health literacy } \\
\text { - Application } \\
\text { of innovative } \\
\text { information } \\
\text { technology } \\
\text { - Procurement and } \\
\text { management of } \\
\text { finances } \\
\text { - Expansion and } \\
\text { supplementation } \\
\text { of local } \\
\text { community } \\
\text { resources and } \\
\text { establishment } \\
\text { of governance }\end{array}$ \\
\hline
\end{tabular}

Figure 2. National Health Plan 2030 framework. Source from: Ministry of Health and Welfare. The 5th National Health plan (20212030). Seoul: Korea Health Promotion Institute; 2021 [19]. 
years to 2.9 years by 2030. Regarding the regional gap in particular, the average HLE of the top 10 cities/counties/boroughs was 74.2 years, whereas that of the lowest 10 cities/counties/ boroughs was 65.2 years, reflecting an 8-year difference.

\section{POLICY IMPLICATIONS OF HEALTH PLAN}

\section{Establishment of a Sustainable Long-term Plan Through Sufficient Preparation}

Establishing a national long-term plan involves analyzing current social conditions and future policy directions for the promotion of sustainable policies in the future. Furthermore, the overall flow of health promotion policies can be derived by analyzing the establishment and improvement of relevant legal systems and the development process of policies and projects in different periods. Unlike HP2010 and HP2020, which were evaluated and planned during a 1-year period, HP2030 was prepared and established over a sufficient period of time, considering that it is a long-term plan; this is the most substantial change from the processes involved in previous plans. Specifically, preparations began 4 years ago, and it was possible to create a virtuous cycle of research, wherein a basis was established for research and a plan was constructed based on the results of that research to implement a HP.

In 2017, the HP2020 indicators, and the project as a whole, were analyzed in depth to develop a system to promote future plans and identify pending issues. Current conditions were examined through international forums with the governments of the United States (Healthy People 2020) [20] and Japan (Healthy Japan 21), which dealt with establishing long-term plans related to health, as well as with the WHO to reflect international trends, alongside discussions to establish future plans. Three years ago (in 2018), studies were conducted centering on tasks that required preliminary review for the establishment of the plan after analyzing the problems to prepare the basis for the plan, and expert forums were held. In 2019,
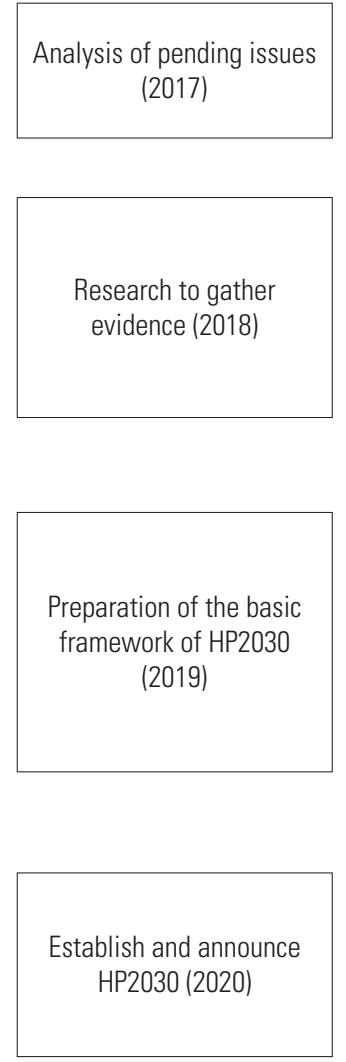

\begin{tabular}{|l|l|l|}
\hline Establishment of plan & Evaluation & Feedback \\
\hline
\end{tabular}

\begin{tabular}{|c|c|c|}
\hline $\begin{array}{c}\text { Analyze HP and relevant } \\
\text { long-term plans }\end{array}$ & Year-round monitoring & $\begin{array}{c}\text { International forum } \\
\text { (WHO, the US and Japanese } \\
\text { governments) }\end{array}$ \\
\hline$\downarrow$ Identify pending issues & $\downarrow$ Evaluation results & $\downarrow$ Policy analysis \\
\hline $\begin{array}{l}\text { - Develop HP2030 logic model } \\
\text { - Develop HP2030 establishment } \\
\text { strategy } \\
\text { - Develop a platform for } \\
\text { calculating HLE }\end{array}$ & Set HP2020 evaluation directions & Expert forum \\
\hline
\end{tabular}

\begin{tabular}{|c|c|c|}
\hline$\downarrow$ Develop logic model & $\downarrow$ Set evaluation direction & $\begin{array}{c}\downarrow \text { Expand local government and } \\
\text { public participation }\end{array}$ \\
\hline $\begin{array}{c}\text { Set the HP2030 basic framework } \\
\text { and basic principles }\end{array}$ & $\begin{array}{l}\text { Evaluate HP2020 } \\
\text { (qualitative, quantitative) }\end{array}$ & $\begin{array}{l}\text { - Organize HP establishment } \\
\text { committee } \\
\text { - Listening to local government } \\
\text { opinions } \\
\text { - Policy proposal through public } \\
\text { participation }\end{array}$ \\
\hline
\end{tabular}

$\downarrow$ Confirm basic framework and strategy details

$\leftarrow$ Reflect major evaluation details

$\downarrow$ Public participation

Establish sub-divisions

- Operate an online hearing

- Promotion of the policy through public participation

Figure 3. National Health Plan (HP) establishment process. WHO, World Health Organization; HP2030, National Health Plan 2030; HLE, healthy life expectancy. 
the vision, general goals, and basic principles were developed and agreed upon to set the overall framework of the HP2030. In addition, the framework was supplemented through the "public policy proposal contest" for public participation. In 2020, the basic framework of HP2030 was confirmed, sub-divisions and areas were established, and indicators and projects for each area were prepared (Figure 3).

\section{Change into a Policy That Everyone Participates in and Makes Together}

While establishing the basic principles of HP2030, it was not only decreed that anyone can take part in the plan, but that this value should be put in place while establishing this plan. A plan is truly national only if it involves the participation of the public, as well as government and private sector experts, in proposing and making the policy. Because the vision and goal of the long-term plan reflect the current social environment and implicitly express the direction of development pursued by the country, the current citizens of Korea are of the utmost importance.

The vision of HP2030 is a "Society Where All People Enjoy Lifelong Health."This vision was established based on consensus between the government and private sector experts, and a civic proposal, "A Republic of Korea where All People are Healthy," was accepted through the policy proposal contest to expand the participation of the people in the policy-making process and to actively reflect their opinions in order to complete the comprehensive vision.

A comparison of the vision of HP2030 with those of previous plans helps to more clearly conceptualize some of the plan's most salient goals. The vision for the first HP, "A Society Where a Healthy Long Life up to 75 Years of Age Can be Realized," introduced the concept of $\mathrm{HLE}$, and the second vision, "A Healthy World That All People Enjoy Together," introduced the concept of the people. The third and fourth visions, "A Healthy World That All People Make and Enjoy Together," introduced not only the concept of enjoying the healthy world together, but also the active concept of making it together. The vision of HP2030 expanded its scope from the nation to all people. By "All People," it emphasizes health equity between genders, classes, and regions and expanded its target from the nation to all people, which is quite meaningful. Moreover, the meaning of a society that enjoys lifelong health was strengthened by guaranteeing the right to health throughout the entire life cycle from birth to old age and embracing the entire society, in- cluding the government.

The task of improving health literacy was also selected through the people's policy suggestions as a topic area for HP2030, and some of the people's suggestions in the areas of nutrition and physical activities were selected and reflected.

\section{Improvement of Universal Health Standards and Health Equity}

Regarding the improvement of health equity, the symbolic general goal was made more concrete to emphasize health equity, which had drawn little interest in the past, and reinforce its effectiveness as a general goal.

The most important goals to achieve by 2030 are the general goals: extension of HLE, and improvement in health equity. However, an important difference from HP2020 is that the data source on HLE was changed from the WHO to Korean data by establishing a basis for calculating HLE based on circumstances in Korea through research and development that continued for the past 3 years, leading to Korean calculations of HLE. The WHO's calculation cycle was irregular, the basis for the calculations was unclear, and it was not possible to monitor the HLE gap between income levels and between regions. Through research and development, it became possible to calculate not only the HLE of the population, but also the HLE at the regional level in order to improve health equity based on regular quantitative assessments of the indicators.

Furthermore, it is necessary to establish a feedback system to reinforce the policy for vulnerable groups identified based on the data collected through the system by using the performance indicator monitoring system of HP2030.

\section{CONCLUSION}

HP2030 strengthened the connection with international health promotion policies by fully reflecting international trends such as the UN's SDGs and the WHO's NCD prevention plan, in line with Korea's international status. For HP2030, a system was also prepared wherein many relevant plans of the central and local governments can be consistently centered on the HP.

With the announcement of HP2030, which presents the goals and directions of national health policy for the next 10 years, this study sets out the national visions and goals and suggests strategies to cope with changes in the future. It is necessary to intensify collaboration with relevant ministries, local governments, and agencies in various fields to further concretize the 
support for prevention-centered health management as a national task, and to develop a health-friendly environment that considers health in all policy areas. Such strategies should be especially be promoted in connection with the long-term health-related plans of the central and local governments. To promote effectiveness, a connection should be ensured between the national health-related long-term plan and the basic plan for each area by respecting the basic directions of the visions and goals of health-related plans, including public healthcare plans and local healthcare plans, while unifying related indicators such as HLE and health equity. Moreover, ministries and local governments should actively collaborate to improve health equity by improving the health level of all citizens and reducing the health gap by region and income.

HP2030 involves many changes and is the product of lengthy deliberations. Nonetheless, it is necessary for stakeholders, including ministries and local governments, to strengthen the connection between the master plan and basic plan by evaluating, deliberating on, and regularly monitoring execution plans in order to strengthen the effectiveness of HP2030.

\section{Ethics Statement}

This paper is a special article based on literature review, so it did not need ethical approval.

\section{CONFLICT OF INTEREST}

The author has no conflicts of interest associated with the material presented in this paper.

\section{FUNDING}

None.

\section{ACKNOWLEDGEMENTS}

None.

\section{AUTHOR CONTRIBUTIONS}

All work was done by YO.

\section{ORCID}

Yumi Oh https://orcid.org/0000-0003-2003-8690

\section{REFERENCES}

1. Oh Y. Current status and further tasks of the health promotion policy: focusing on the National Health Plan. Korean J Health Educ Promot 2017;34(4):11-25 (Korean).

2. Ministry of Health and Welfare. The 4th Health Plan (20162020). Seoul: Korea Health Promotion Institute; 2015, p. 1-78 (Korean).

3. Jeong JG, Choi JW. Theories of policy sciences. Seoul: Deamyung; 2017, p. 407 (Korean).

4. World Health Organization. World health statistics 2016: monitoring health for the SDGs, sustainable development goals [cited 2021 Apr 1]. Available from: https://apps.who.int/iris/ handle/10665/206498.

5. World Health Organization. Health in 2015: from MDGs to SDGs [cited 2021 Apr 1]. Available from: https://www.who.int/publications/i/item/9789241565110.

6. World Health Organization. Global status report on noncommunicable diseases 2014 [cited 2021 Apr 1]. Available from: https://www.who.int/nmh/publications/ncd-status-report2014/en/.

7. Korea Health Promotion Institute. Directions for National Health Plan through analysis of health policy. Seoul: Korea Health Promotion Institute; 2018, p.1-25 (Korean).

8. Bae SS, Park NS, Park JH, Shin DS, Lee YS, Lee TJ. Evaluative study of the new health plan 2010. Chuncheon: Hallym University; 2011, p. 1-23 (Korean).

9. Korean Law Information Center. National Health Promotion Act, Law No. 16719 (Dec 3, 2019) [cited 2021 Apr 1]. Available from: https://www.law.go.kr/법령/국민건강증진법 (Korean).

10. Ministry of Health and Welfare. The 3rd National Health Plan (2011-2020). Seoul: Korea Health Promotion Institute; 2011, p. 79-82 (Korean).

11. Oh Y, Cho I. Policy directions to improve collaboration of central and local government for effective health promotion policy. Health Policy Manag 2020;30(2):142-150 (Korean).

12. Oh Y. A study on performance evaluation for achieving national health promotion goals: focused on the Health Plan 2020. Korean J Health Educ Promot 2018;35(4):19-34 (Korean).

13. Kim E, Oh Y, Cho Sl. Strategy for improving National Health Plan 2030 development guided by assessing compliance with the 2020 Plan guidelines. Korean J Health Educ Promot 2020:37(1): 33-44 (Korean).

14. Shin SM. Health life expectancy is 73.3 years old, and will be extended by 2.9 years by 2030. Yonhap News; 2021 Jan 27 
[cited 2021 Apr 8]. Available from: https://www.yna.co.kr/view/ AKR20210127103200530 (Korean).

15. Yoon SJ. A study on the development of a platform for measuring the health life expectancy of Koreans for realization of precision public health. Seoul: Korea University; 2020, p. 45-48 (Korean).

16. Kim DJ, Yun KJ. Jung Y, Cae SM, Choi JH, Bae JE. Evaluation of National Health Plan 2020. Sejong: Korea Institute for Health and Social Affiars; 2019, p. 32-36 (Korean).

17. Park SW, Kim CH, Ryu DH, Shin MH, Lee YH, Lee JH, et al. A study on the establishment direction of the 5 th National Health Plan. Daegu: Catholic University of Daegu; 2018, p. 213-217 (Kore- an).

18. Cho SI, Kim E, Kwon SH, So YH, Jeon ES. Developing strategy for systematizing National Health Plan. Seoul: Seoul National University; 2018, p. 1-20 (Korean).

19. Ministry of Health and Welfare. The 5th National Health Plan (2021-2030); 2021. Seoul: Korea Health Promotion Institute; 2021, p.16-20 (Korean).

20. Office of Disease Prevention and Health Promotion. Development of the national health promotion and disease prevention objectives for 2030; 2019 [cited 2021 Apr 1]. Available from: https://www.healthypeople.gov/2020/About-Healthy-People/Development-Healthy-People-2030/Framework. 